\title{
TOURISM AND ECONOMIC CRISIS MANAGEMENT WITHIN APEC. CASES: PHUKET (THAILAND) AND LOS CABOS $(\mathrm{MEXICO})^{1}$
}

\author{
A. GÁMEZ ${ }^{1}$, A. IVANOVA ${ }^{1} \&$ K. CAMPIRANON ${ }^{2}$ \\ ${ }^{1}$ Department of Economics, Universidad Autónoma de Baja California Sur, La Paz, BCS, México. \\ ${ }^{2}$ DPU International College, Dhurakij Pundit University, Bangkok, Thailand.
}

\begin{abstract}
The Subprime Crisis in 2008 showed the need to devise mechanisms of economic adaptation and prevention of losses in a context of extreme vulnerability, which defied traditional views of economic and political organization worldwide. For the tourism sector the challenge doubled since it is normally highly vulnerable to external impacts, which in turn tend to compromise the capacity of recovery of tourist destinations. This paper offers a discussion of responses from the lodging sector to the world economic crisis in two APEC tourism destinations: Phuket (Thailand) and Los Cabos (Mexico), stressing employment policies. Such destinations reflect a dynamic model of foreign investment and demand, and are locations of processes of economic and demographic growth that foster controversial local and external interactions. The research was carried out utilizing semi-structured in-depth interviews applied face-to-face to high level hotel executives. One of the most important results points out that personnel management is one key feature for crisis resilience and to further competitiveness.

Keywords: APEC, International crisis, Mexico, personnel management, Thailand, tourism vulnerability.
\end{abstract}

\section{INTRODUCTION}

The Subprime Crisis, which originated in the rise in subprime mortgage delinquencies and foreclosures which led to the collapse of other financial markets in the United States (U.S.) in 2007, fully hit the world economy in 2009 bringing about a recession of long-lasting effects. Although crises in the international economy are not new, this time the high vulnerability of the advanced economies to global financial shocks was paramount. An analysis of the reasons for the Subprime Crisis is beyond the scope of this paper, but it evidently exposed, on the one hand, the shortcomings of the nature of the financial system in developed countries [2] and, the rapid resilience of emerging economies, which allowed them to have a quicker recovery [3]; on the other hand, it revealed its multidimensional nature, which went beyond the mere financial realm and questioned the sustainability of the system itself [4].

In a context of 'debt pressures sapping growth, risk of instability in the core of the global economic system, and social tension' [5], the importance of strengthening cooperation as a means to resist global turbulences has been put forward. Earlier, at the intraregional level, recommendations were made to develop financial cooperation and a more mature internal market for final goods and services especially in East Asia [6], as well as to look for the strengthening of domestic markets. However, there have also been alerts about the dangers of (sub) regional protectionism $[7,8]$ and the need to devise mechanisms to cope with unsustainable practices [9].

1 We are grateful to University Mobility in Asia Pacific (UMAP) programme for funding the research that made this work possible. A first version of this paper was presented in the Wessex Conference Ravage of the Planet 2011 [1]. WIT Transactions on Ecology and The Environment, Vol 161, () 2012 WIT Press www.witpress.com, ISSN 1743-3541 (on-line) doi:10.2495/ST120081

(C) 2014 WIT Press, www.witpress.com

ISSN: 1743-7601 (paper format), ISSN: 1743-761X (online), http://journals.witpress.com

DOI: $10.2495 /$ SDP-V9-N2-143-157 
In the disarray surrounding the international economy, the tourism sector proved capable for recovery that is expected to continue in the forthcoming years. Following the decline registered in 2009 , the sector rebounded strongly in 2010 when international tourist arrivals increased $6.6 \%$ to reach 940 million, and international tourism receipts grew by $4.7 \%$ in real terms to mean US\$ 919 billion. Also, international tourism grew by almost 5\% in the first half of 2011 and a new record of 440 million arrivals was reached. With the understandable exception of the Middle East and North Africa, which have suffered major conflicts along 2011, major tourism regions showed positive results, even in the case of Europe (an overall increase of 6\% in relation to 2010). With 6\%, the Americas was slightly above the world average, while South America reached 15\%; however Asia and the Pacific grew 5\%, in comparison to its 13\% growth in 2010 [10].

International tourism has been among the world's largest export earners and one of the most important sources of employment, making it a key industry in many countries for many years. With the exception of 2008 and 2009, when the most hard times of the crisis combined with health hazards that hindered its growth, and negative rates of 1 to $2 \%$ were experienced, as air travel and hotel performance slowed down in respect to a previous decade of impressive growth [10, 11], the tourism sector contribution to GDP and employment has been considerable. In terms of its total contribution, including its wider economic impacts, travel and tourism is forecast to represent $9.1 \%$ of GDP (US\$5,991.9 billion) and 9.6\% (US\$9,226.9 billion) by 2021 . Regarding employment, including jobs indirectly supported by the industry, it is forecast to rise from 258.6 million jobs $(8.8 \%$ of total employment) in 2011 to 323.8 million jobs $(9.7 \%$ ) by 2021. As a whole, the travel and tourism SECTOR is to be $5.8 \%$ of total exports in 2011, and is expected to be US\$1,789.2 billion (4.7\%) in 2021 . A dynamic trend of investment is behind this outlook, insofar as the sector has involved US\$652.4 billion or $4.5 \%$ of total world investment in 2011, whereas it is forecast to rise by $5.4 \%$ per year to reach US $\$ 1,487.9$ billion (or 4.6\%) of total investment in 2021 [11].

The wide region along both sides of the Pacific Rim has been important in the trend referred to above. The Asia Pacific Economic Cooperation mechanism (APEC), a heterogeneous region of 21 economies (Fig. 1) which altogether account for $40 \%$ of the world population and contribute

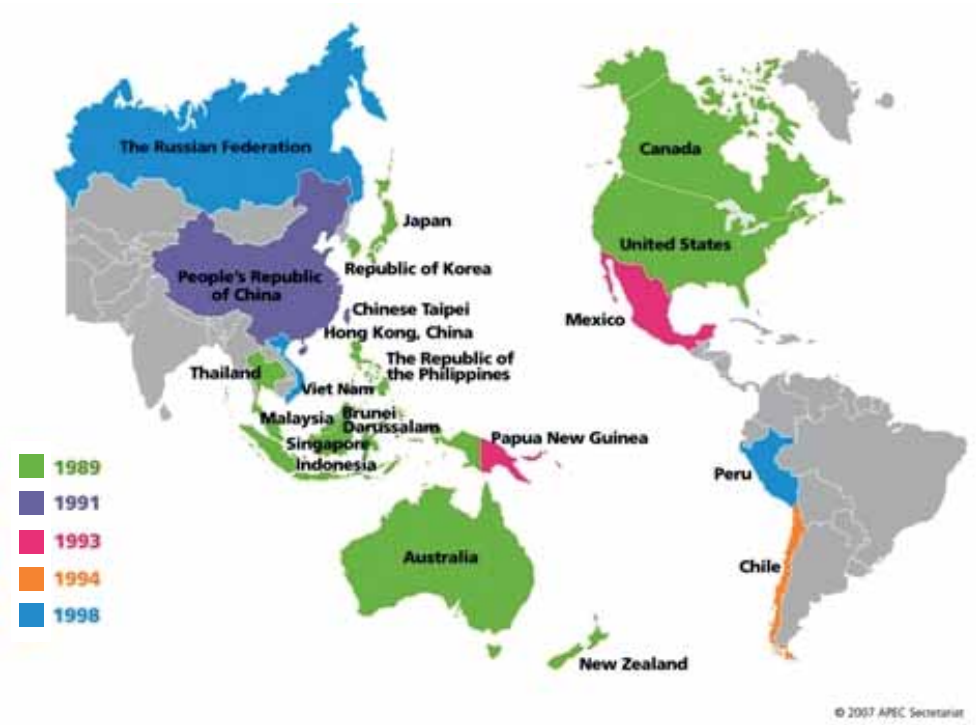

Figure 1: APEC member economies [7]. 
$60.2 \%$ of global output [7], has been site to the fastest growing tourism regions since 1990. According to the World Tourism Organization's division of tourism regions, Asia Pacific is only second to Europe, while the Americas region is third. Up to the subprime crisis, international tourist arrivals to Asia and the Pacific grew at an average annual rate of $7.1 \%$. Not surprisingly, tourism in this region became the motor propelling global tourism in general, gradually changing the world tourism scenario [12].

APEC has been relevant to this outcome. Although originally created as a mechanism for regional trade liberalization, the tourism sector growth and its possibilities for productive linkages gave way to the creation of the Working Group on Tourism (TWG) within APEC. The TWG is a forum to agree on common employment standards in tourism (certification and accreditation of professional practices), as well as to identify and propose measures to reduce and eliminate obstacles to its development.

Those measures recognize that tourism is an important area for the members' economy in the region. APEC hosts destinations which have traditionally been relevant in the international tourism market in terms of flows of visitors and revenues, pointing out the special importance of the tourism personnel. This is the case of the countries selected for this research: Mexico and Thailand. Most APEC members rank among the 20 topmost important countries in the world (out of a total of 176) in terms of tourism.

By sub regions, in North America (United States, Canada and Mexico) travel and tourism represents $10 \%$ of gross national product and $11 \%$ of employment; this is second only to Europe. The North-Eastern sub region of Asia ranks third worldwide [11]. Notwithstanding this, the tourism sector in APEC is far from having a secure future. Current growth rates of 4-5\% long-term average ought to be placed in the larger context of the sector's collapse in 2008-2009.

In spite of its relative recovery, the impact of the economic crisis on international tourism has been large. Projected tourism growth may suffer from further economic downturns, related to factors such as more expensive fuel prices, increasing public deficits, investment contraction and unemployment [13].

This paper refers to Phuket (Thailand) and Los Cabos (in Mexico's north-western peninsula) as examples of a luxury-type of international seaside destinations, which target foreign markets and are, thus, more vulnerable to international shocks. Such cases represent the integration of once remote areas to the international tourism market, which has been welcomed given the opportunities for economic returns, the potential for regional development, and the array of positive interrelations that tourism fosters. However, as in many other cases [14], those regions share a common pattern that is characterized by the lack of local capital, know-how mechanisms, and capacity building.

The situation referred to above has made the sector's growth dependent mainly on foreign investment. As a consequence, the most profitable areas of tourism are externally run and the benefits derived from economic growth tend to follow that same pattern. This set of factors has led to both positive and negative outcomes. In the first case, due to their size and resources, resorts which are part of international networks can better resist shocks; in the second case, profits tend to concentrate abroad and the immediate impacts of the crisis are felt strongly at the local level, as the economy functions around investments from abroad, in third place the foreign investors many times prefer to hire specialized workers from their countries in state of local habitants In this regard, devising mechanisms of crisis prevention and recovery play an important role for both the private sector in terms of loss minimization, and for the public sector as a way to avoid long-term economic stagnation and loss of employment [15].

An overview on how economic crisis has been conceptualised and the approaches to crisis management in the tourism sector is presented below in order to frame the case studies' results displayed in sections three to five of this paper. 


\section{ECONOMIC CRISIS MANAGEMENT AND EMPLOYMENT IN TOURISM}

Developing an understanding of crisis management in tourism during an economic crisis requires a definition of crisis and the types of crisis. The impacts of crises on tourism will then be explored in detail, followed by the concept of crisis management and economic crisis management. There have been several attempts to define the concept of crisis [16], with a whole tier of academic work concerned essentially with this task [16]. However, having a specific definition is important as how to define a subject, since this dictates to a large extent how one approaches it [3].

There are several definitions of a 'crisis'. At its core however, the concept refers to 'an adverse incident with an unpredictable outcome', as similarly proposed by a considerable number of authors in crisis management, e.g. [3,15, 17-19]. Crises have been defined as situations which have reached an extremely difficult or dangerous point, and a time of great disagreement, uncertainty and suffering [20]; and also as an unstable or crucial time or state of affairs in which a decisive change is impending [21]. Along very similar lines, Moreira [22] argues that crises are periods of great uncertainty in which predictability and control are lost or severely diminished.

There are a number of different approaches on how the impact of crises can be viewed. Bland [23] recognized that crises can affect human safety, the environment, and/or a product or corporation's reputation, which has either received, or been threatened by, adverse publicity. The Pacific Asia Travel Association [21] states that a crisis also affects long-term confidence in an organization or a product, and may interfere with an organization's ability to continue operating normally including job cuts.

Mitroff et al. [24] added that a crisis can affect the entire organization; a major product line; a business unit; an organization's financial performance; or even cause the death or adversely affect the well-being of customers, employees, the surrounding community, and the natural environment. On top of that, a crisis can destroy the public's basic trust in an organization, along with its reputation and public image.

Crises are largely unpredictable events [18, 25-28]. While the actual timing, location, and severity of crises cannot be accurately predicted, Laws et al. [29] have suggested, nevertheless, that it is possible to learn from previous crises, to pre-plan emergency procedures, and to lessen the severity of a crisis by adopting appropriate precautions.

Since economic crises lead to job losses, and price and investment reductions [30], during an economic crisis, it is recommended that tourism organizations focus on markets that will generate revenue [31]. In turn, discounting has been widely used as a marketing strategy to attract potential markets. In fact, a number of tourism organizations consider discounting to be one of the most important marketing strategies. Tourism Internet Marketing [32] argued however that discounting is not the most effective strategy during an economic crisis and is not recommended due to a number of reasons.

The above is due to the fact that discounting sends a very dismissive signal to past loyal customers - essentially saying their loyalty is worthless and implying that the profit margin is so high that the supplier can afford to discount indiscriminately now. Secondly, it reinforces the notion that if the seller doesn't value their own product, why should the buyer? Thirdly, it further commoditises the industry and, by necessity, downgrades service levels and causes job cuts. How do 5 star hotel properties manage to offer over 50\% discounts without reducing staff and dropping service levels? Fourthly, it will make it very difficult to raise prices and capture back customers when interest rates, taxes and the price of energy, carbon and other key inputs rise, and rise they most certainly will within the next 18-24 months [32].

To cope with an economic crisis effectively, tourism scholars have suggested a number of best practices. One of the most important policies is the capacity building and personnel management. 
Cooperation between public and private sectors appears critical for the sustaining of international tourism in a region. Arguably, while tourism in a single economy is likely to remain more vulnerable in the economic downturn, it is believed that collective strategies through collaborations, regional cooperation, and partnership will serve as effective coping strategies for the recovery of inbound and outbound tourism [33].

\subsection{Thailand: Impact of the crisis on employment}

The global financial and economic crisis has impacted national labour markets in Thailand through a variety of channels, including declining demand for labour, downward pressure on wages, falling remittances, decreased jobs and rising informal employment, among others.

In Thailand, the labour market was impacted through the export manufacturing channel. In particular, as overseas consumer demand fell, Thailand, as an economy with extensive linkages to the global production chain, faced increasing retrenchments in this sector. Many of these export industries (such as textile, garment, electronics) are not only labour-intensive but also consist of a majority of female workers who have been disproportionately susceptible to the job cuts $[34,35]$. The share of employment in manufacturing fell from 15.1 per cent in the third quarter of 2007 to 13.8 per cent in the third quarter of 2008 , while the share of employment in agriculture rose slightly, absorbing some of the losses in manufacturing [36]. In addition, according to the Fiscal Policy Office of the Ministry of Finance, unemployment in 2009 could reach 1.13 million, a substantial rise from the third quarter 2008 level of 450,000 [37].

The most affected sectors are the automobile, electronics, hotel and tourism industries. All subcontracted workers in the informal sector would be affected. As they have little bargaining power, they are among the first being laid-off. Therefore, a shift to informal and vulnerable employment is observed. When an external shock causes an initial fall in formal sector urban employment, a majority of workers in Thailand simply cannot afford to remain unemployed [35]. Their options are to seek new wage employment, turn to the informal service sector where pay is often lower and job quality is inferior, or migrate back to rural areas to pursue work, typically in relatively low productivity agriculture.

\subsection{Stimulus plan to curb impact of crisis in Mexico}

The Mexican government 54 billion dollar economic recovery plan aimed at helping the local economy weather the global financial crisis, with measures like freezing gasoline prices and boosting spending on public works. The price of natural gas was be reduced by 10 per cent, and electricity rates for industry were slashed by up to 20 per cent. The government set aside financing to help poor families replace old appliances with more energy-efficient ones, and increased spending on the construction of low-income housing and development of the countryside [38].

In addition, at least 20 per cent of government purchases were performed from small and medium companies, and workers were allowed to draw more easily on their retirement funds in private banks. The measures were a part of a 'national agreement to favour family economy and employment' [39]. Although it was presented as an arrangement between government and business, most of the actions were financed by the state [40]. The plan was funded by an unprecedented proportion of oil revenues and taxes, and generated a fiscal deficit for the first time since the mid-1990s, of nearly two per cent.

The Mexican federal government implemented fiscal measures amounting to an injection of one per cent of GDP, which included cuts in energy prices, extra investment in roads, railways and oil wells, and measures to extend medical cover, welfare benefits or temporary jobs to the unemployed 
$[20,41]$. That came on top of an expansionary budget for 2009 and a previous fiscal stimulus in October, 2008 (which included extra payments to poorer Mexicans). Together with Australia, Poland and Canada, Mexico was projected to be the most pro-active in this domain, with an increase in public investment as a response to the crisis close to one per cent of 2008 GDP or more [42].

Mexico's tourism sector was hit simultaneously with the financial crisis and the influenza crisis which left hotels, restaurants and other tourism-related businesses, literally empty. In order to weather the crisis and prevent mass layoffs or cutbacks in income (including 'tips', often the principal source of income for lower-level workers), the Mexican government created the Programa de Apoyo Emergente a Trabajadores del Sector Servicios (Program of Emerging Support to Sector Services Workers), in which the Temporary Employment Program (Programa de Empleo TemporalPET) and the National System of Employment (Servicio Nacional de Empleo-SNE) were the outstanding landmarks [39].

Considering the previous context, the following sections deal with results from a research that was conducted simultaneously in Phuket and Los Cabos, in order to assess the effects of the economic crisis on the lodging sector and their responses to countervail them.

\section{TOURISM HUMAN RESOURCES AND CRISIS IN PHUKET, THAILAND AND LOS CABOS, MEXICO}

\subsection{Methodology}

The study relied on in-depth interviews with high-level executives (e.g. directors, general managers, company advisors, and presidents) at hotels in Phuket (Thailand) and Los Cabos (Mexico) that had already been in business prior to 2008, when the global economic crisis started. In order to assess the degree of vulnerability and adaptability in the tourist lodging sector, we sought to identify the potential attitude and behavioural change with respect to hotel action plans in relation to the current economic crisis as well as natural contingencies. The selection of the sample was based on the criteria of hotel size and category, so that it reflected the hotel structure in the area (most are hotels ranging from 4 to 5 stars), thus being representative of the nature of those expensive tourist resorts. Interviews related to the perception of signals that the crisis would be so strong; the period and areas of the hotel that felt most the impact of the crisis; effects on employment and purchases to suppliers; current and planned recovery strategies to deal with the crisis; perceptions of recovery; and participatory planning within the company.

The in-depth interviews in Phuket (25 interviews), were all undertaken in October 2010, and in Los Cabos (34 interviews) in November-December 2010. The interviews were applied face-to-face. Each interview lasted between 30 and 40 minutes, since extended interviews (beyond 45 or 50 minutes) were not possible given that most interviewees were senior management with busy schedules.

\subsection{Tourism and vulnerability in Phuket: Perceptions in the lodging sector about the crisis}

One of the most popular tourist destinations in Thailand is Phuket. Phuket is Thailand's largest island and it is often dubbed as 'the Pearl of the Andaman', or 'the Pearl of the South'. Its natural resources, rocky peninsula, limestone cliffs, white powdery beaches, tranquil broad bays and tropical in-land forests contribute to making it the South's wealthiest, busiest, most visited and most popular island and province [42].

Like other tourism destinations in Thailand, Phuket has been severely impacted by the contraction of long-haul markets [11]. Strongly affected by the 2004 tsunami, Phuket's tourist business recovery 
was endorsed by The Tourism Authority of Thailand's statistics, but the current global economic crisis sent visitor numbers plunging once again: the number of tourists coming to the Andaman coast had fallen in 2009 [30].

The Phuket hotel industry has suffered severe reductions in revenue per available room (RevPAR) and average room rates (ADR). Wide-scale discounting of $20 \%$ led to losses in 2009 of approximately US\$300 million in room revenue. Phuket's annual visitor arrivals of 2.9 million in 2009 were only equivalent to those at the 2007 level [30]. Arrivals at Phuket International Airport during the economic crisis period were significantly lower than the number of visitor arrivals during the same month the year before. In addition, hoteliers hit bottom lines when they attempted to induce demand and meet increasing consumer pressure for lower rates. Virtually every chain scale tier was affected with the exception of the budget and economy segment. In summary, 2.9 million tourists visited Phuket in 2009 with an island-wide average occupancy of $64 \%$. This meant that average rates and revenue per occupied room dropped by $20 \%$ and $22 \%$ respectively compared to 2008 [30].

The main concern of tourism in Phuket is over-development, especially in the low season, in which there is low tourist demand yet high competition among local tourism organizations. Although Phuket's tourism industry has been affected by over-development, it still has a competitive advantage over other destinations in Thailand.

Internationally, Phuket has always been compared with Bali. During the Bali bombing crisis, a number of tourists, primarily Australians, move their holiday destination to Phuket due to safety concerns. However, Bali is now growing again, and Phuket is going down in terms of attractiveness. This is because the tourism authority at Bali is employing effective strategies to promote Bali as a destination. In fact, what Bali has done is similar to what Thailand did after the tsunami crisis.

For the study on Phuket that follows, hotels with room rates of at least 133 USD per night, which is an average room rate in Phuket [43], were the target of in-depth interviews with key informants leading to the identification of five critical success factors, as follows: Crisis Personnel Management, Crisis Market Segmentation, Crisis Marketing Promotion, Crisis Collaboration, and Crisis Management Plan.

During economic crises there is a price issue as people tend to avoid travel in order to save money. Traveling is not as important as the basic needs in people's lives such as food and accommodation and, therefore, travel spending is one of the first expenses to be reduced by those who have been affected by an economic crisis. A weaken Euro currency is a clear example that has resulted in the decrease of long haul scheduled flights from Europe to Thailand.

Regarding Phuket, the financial effects did not stop some visitors but made them more budgetcautious with their spending; they spent less accordingly, such as having dinner at local restaurants instead of eating at the hotel restaurants. They were short-haul travellers, what explains that long haul market has not bounced back from the economic crisis.

Respondents also pointed that the airfare is not the only expensive part of the holiday, as there are cheap flight alternatives. In fact, hotel stay is another costly expenditure as tourists will be charged per night plus tax. This is why a number of tourists who have a tight budget are shortening their duration of stay in order to reduce costs.

Interviewees stated that the economic crisis impacted on the tourism industry in Phuket, but not too much. It should also be considered that Phuket's competitors, primarily beach destinations, have also been affected by the economic crisis. At this point, respondents highlighted that Phuket has a competitive advantage over other destinations by having a variety of value-for-money tourism products. 
The policies and instruments implemented as response to the economic crisis by lodging businesses in Phuket were the following:

Crisis Personnel Management. It should be pointed out that overhead costs amount to the tourism business' biggest challenge. At the same time, employees are the most valuable asset. In turn, tourism organizations in Phuket were cautious with fixed and variable costs during the economic crisis, when generating revenue became difficult. It was important to have a personnel management plan. This is endorsed by Ruff \& Aziz [44], who states that organizations that communicate well internally tend to communicate better overall, achieving more favourable perceptions among external audiences. Education was also a factor that influences the Thai tourism industry. Most educational initiatives in Thai tourism have been led by higher and tertiary level education institutions and by successful Thai hotels. For example, the Dusit Thani Hotel is providing strong training programs. Yet, our study pinpointed that Thai hotel employees need to develop English and Information Technology skills that can make them more competitive when contending for jobs against foreign citizens.

Crisis Management Plan. As mentioned in the reviewed literature above, the first critical success factor for tourism organizations is to have a crisis management plan in place. It should be noted, however, that a crisis management plan is only a basic guideline. The plan needs to be adapted to the situation, location, and market. Such findings have been supported by tourism scholars, who state that each crisis requires a different crisis management plan $[2,45]$.

Crisis Market Segmentation. Although Phuket has successfully attracted a number of tourists from both overseas and domestic markets in the past, keeping this trend during the economic crisis became increasingly difficult. From our study is was clear that, for overseas markets, it is vital that the tourism industry in Phuket focuses either on markets that have not been affected, or emerging markets. Phuket is a seasonal destination; promoting it during the low seasons, six months from May to October, was extremely challenging [43]. The crisis stressed the need to match the right market with the right season regarding Phuket's tourism industry; this implies searching for dynamic solutions.

Regarding Phuket's domestic market, results from our research supported tourism literature which shows that Thai tourists perceive Phuket as a rather expensive destination [46], which primarily welcomes overseas tourists [47]. Although Phuket can successfully attract domestic tourists, those tourists are likely to spend less than overseas tourists and also tend to stay at low-medium level hotel accommodation [30]. Therefore, medium-high level hotels in Phuket would need to work harder to attract domestic tourists, which could afford their products; this, of course, will depend on the country's economic performance.

Crisis Marketing Promotion. Tourists are generally cost-conscious during an economic crisis. Hence a marketing promotion offered by tourism organizations needs to explain the possibilities of having an affordable quality holiday. Findings from this research have shown that there are largely two approaches to doing this, either by discounting or by adding value to the tourism products. Both approaches are discussed below.

Adding value to the tourism products appears to be a superior approach for attracting customers during an economic crisis. The Tourism Authority of Thailand (TAT), for example, launched a global campaign 'Amazing Thailand, Amazing Value' in 2009. By emphasizing Thailand's worthwhile advantages, TAT can better address travellers who still like to go on vacation, but to a less-costly destination. A survey by CNN has confirmed the campaign's effectiveness, titling Thailand as the best value destination in Asia-Pacific [42]. Our study showed that, in order for the tourism industry in Phuket to maximize product value from a limited marketing budget, effective collaboration with tourism stakeholders is needed.

Crisis Collaboration. A common problem during an economic crisis happens when tourism organizations compete against others by using discounting strategies. It is therefore suggested that 
tourism organizations work hand-in-hand with suppliers in order to achieve an economy of scale which would lower the total product costs. As Beirman [8] has explained, collaboration among tourism organizations, together with the government's support, would enable them to sell bulk tourism products as an attractive value-added package.

Regarding government's push for crisis collaboration, The Phuket News [19] reported that the Tourism Authority of Thailand (TAT)'s Phuket Office has recently launched a new campaign, encouraging domestic trips to Phuket from Bangkok. The campaign, 'Phuket Great Time-Click and Go', is a collective effort from over 100 tourism agencies in Phuket and Phang-nga. Whilst this campaign will only be available to Thai nationals, it is hoped an influx of domestic tourists will be able to compensate for the loss of other tourism markets. Nonetheless, research findings have shown otherwise. Some leading tourism organizations, particularly the TAT and Thai Airways, have been criticized for not doing enough to support the tourism industry during an economic crisis situation.

On the side of challenges related to climate change, tourism in Thailand is vulnerable insofar as increasing sea temperatures and sea level along the island could lead to a reduction of the coastline and stronger monsoon seasons. Climate change issues and their implications on the tourism industry of Phuket are still to be further debated, but promoting awareness on its significance as threats and opportunities to the economic development of tourism have started [48]. Overall, the lodging sector, as it stemmed from our study, needs to devise plans to countenance the economic cost of climate change effects.

\subsection{Tourism and vulnerability in Los Cabos, Baja California Sur, Mexico: Perceptions} in the lodging sector about the crisis

Los Cabos (in Mexico's north-western peninsula) has become the second most important seaside tourist destination in Mexico. Located in the southernmost tip of the peninsula of Baja California, 1,100 miles away from the border between Mexico and the United States, it used to be a small fishing town. However, during the last three decades -as a result of a federal government plan to promote seaside resorts in isolated areas- tourism and related activities have shaped not only the area but also the wider economy of the state of Baja California Sur (BCS): about $40 \%$ of the regional economy depends on tourism-related activities, which also directly contributes to about $30 \%$ of the state's employment [49]. La Paz (the state's capital) has a more diversified economic base, but the significance of tourism in the latter municipality has been on the rise over the last 5-10 years, with a growing orientation towards resort projects over large tracts of the Gulf of California seashore, which typically involve a large number of second homes for mainly American and Canadian citizens, hotels, and golf courses.

In 2008, Los Cabos attracted 1.23 million visitors (73\% of total tourists in BCS) and $76 \%$ of the state's 18 thousand rooms are located there (most of them in hotels rated 4 or more stars). It is worth noting that the average income of visitors to Los Cabos is US\$77,000; almost double that in the rest of the country. Daily spending is estimated at 250-450 dollars, what explains its pre-eminence in Mexico's tourism [49]. Enormous amounts of investment have been made and continue in the region. The origin of investors is mainly foreign and $70 \%$ of direct foreign investment to the state has been directed to La Paz and mostly to Los Cabos. The tourism subsector of hotels and lodging has absorbed most of this investment [2].

Los Cabos is an example of a luxury-type of international seaside destinations, which target foreign markets and is thus more vulnerable to international shocks. It represent the integration of once remote areas into the international tourism market, what has been welcomed given the opportunities for economic returns, the potential for regional development, and the array of positive interrelations that tourism fosters. However, as in many other cases [14], this type of region shares a 
common pattern that is characterized by the lack of local capital, know-how mechanisms, and control of commercialization chains, especially regarding tourism resorts. This situation has made the sector's growth dependent mainly on foreign investment. As a consequence, the most profitable areas of tourism are externally run and the benefits derived from economic growth tend to follow that same pattern.

Apart from the set of factors discussed above, the global economic crisis also has had a strong negative effect on Los Cabos' tourism industry. The major impact of the crisis in the hotel sector in Los Cabos was in 2009. Jobs plummeted especially in the construction and tourism-support services sectors, which in turn meant a high level of unemployment [50]. This exposed the high degree of vulnerability of this tourism destination. Among hotels, $83 \%$ declared having noticed early signs that the crisis would be very strong, while only $17 \%$ did not. These signals were mainly related to low occupancy and reservations; to cancellations or room reservations; and, thirdly, to factors such as the opening of new hotels in the area which resulted in more competition in 2009; poor indicators in the economy; staff dismissals and rotation, and the temporary closure of some hotels.

For most, the highest peak phase of the crisis was April 2009, when the United States government warned its citizens not to travel to Mexico fearing a swine flu spread. However, after that emergency which was unwarranted, the economic crisis contributed to the lack of visitors. For almost half of the hotels the summer of 2009 was bad, while a fifth ended the year with serious difficulties. With regard to the operation of hotels, the most affected areas were accommodation (47\%), while for $25 \%$ of them the most damaged area was food and beverages. This figure shows the magnitude of the impacts, since hotel services rest mainly in those two areas. Only one-tenth of hotels had negative impacts in all areas of their operation.

Despite the impact from an economic crisis, stakeholders of hotels in Los Cabos have a high expectation regarding the hotels' continued existence. On the one hand, the size of the business seem to have influenced the degree to which it was affected: Los Cabos is a destination where the presence of multinational or national level hotel chains is very high and defines the local hotel supply; thus it can be expected that these companies have sufficient capacity to cope with the decline in visitors. At the other extreme, although the temporary closure of a hotel was reported, small size and familyowned lodging owners were forced to resist since closure would have meant total bankruptcy. In both cases, though, flexible working conditions to preserve jobs were advanced.

The policies and instruments implemented as response to the economic crisis by lodging businesses in Phuket were the following:

Personnel Management: In spite of experiencing a huge contraction (a loss of 250,000 or $25 \%$ of visitors in 2009), the reduction of employment in hotels was not an immediate strategy to cope with the crisis. Almost $40 \%$ of hotels did not fire any of their employees and only 1 out of 5 fired $10 \%$ of their staff. That is, almost $60 \%$ of hotels kept their staff, although this was at the expense of the workers' income as a trade-off to keep their jobs. On the other hand, more than one third reduced their staff between $20-40 \%$. One of the policies to increase the performance of the personnel is, like in Thailand, to enhance the skills and knowledge building and create opportunities to apply these skills and knowledge. These can be complemented by delegating more responsibility to lower-level management and allowing personnel to have more control over their own work. Of course, introducing some financial or non-financial incentives could also be important.

Supplier Management: On the side of the suppliers, the scene was more dramatic. Almost $40 \%$ of hotels reduced their purchases by half or more; a fifth did so at a rate of between 20-30\%; and only one-tenth did not affect the relationship with its suppliers. This fall in the demand for goods and services had strong implications especially for local suppliers of food and beverages (the most impacted of all), cleaning, maintenance, and entertainment. 
Marketing Promotion: Hotels reacted with recovery strategies to the crisis: $60 \%$ of the hotels offered packages, and discounts to visitors; a fifth opted for advertising, followed by agreements with suppliers to reduce costs. By the end of 2010, 64\% had experienced economic recovery, albeit small; whereas the remaining still had not perceived it. The expectation was that a more decisive recovery would occur during winter, when foreign visitors' influx makes up the high season in the region.

Crisis Management Plan: Considering the profound impacts of the economic downturn on tourism in Los Cabos, it could be expected that corporations designed and coordinated a plan to prevent or adapt to future emergencies. However, while $62 \%$ of respondents considered extreme events (hurricanes, essentially) in their emergency planning, and only a fifth included aspects related to the economic crisis.

Most of the hotels have plans to deal with events such as hurricanes and cyclones, as well as fires, and a hotel devised a new program against tsunamis. Measures to be taken in the case of the economic crisis refer to seeking assistance from the public sector, introducing energy-saving programs, negotiating lower prices with suppliers, increasing sales and improving the quality of the service, reducing working hours to avoid worker lay-offs, offering vacation packages, and reducing fixed costs.

The absence of regional and, in almost half of cases, individual plans to face an economic crisis in the tourism environment is alarming. Therefore, the recovery of the sector has been slow and reactive.

\subsection{Discussion}

As stated above the Personnel Management was one of the most important responses to crisis impacts in both cases of study. The perceptions about the economic crisis and the human resource relevance in Phuket's and Los Cabos' tourism sector are similar. It is recognized that it is very important to effectively respond to and manage the impact of crisis affecting the tourism industry to minimize the negative impacts on the economy and employment. Negative perceptions exist in the lodging sector in terms of the lack of career and promotion opportunities, as well as regarding wages and working conditions. These reasons can account for a high labour rotation, insofar as reduction of work-days and salaries was a means to keep jobs, at least for some time, in the face of a declining tourism demand. The importance to create a standardised curriculum in tourism education and training institutes was also stressed in the interviews.

Hotel owners and managers also require additional knowledge and skills regarding best practice human resource management $[49,51,52]$. Advancing towards this direction would guarantee more resilience to economic crises and natural disasters. This approach does not show any differences in 4 stars and 5 stars hotels. The main difference that can be noted between Thailand and Mexico is that, in the first case, development of skills is prioritised and, in the second case, it higher stress on personnel performance-related policies was observed.

\section{CONCLUDING REMARKS}

The importance of tourism as an international engine of economic growth is manifested in the enormous amount of resources that derive from the travel and tourist industry worldwide, as shown by indicators such as the services account balances, revenues, job creation, and investment in infrastructure, to mention a few. Policy coordination among governments and cooperation within the private sector extensively exemplify the benefits associated with the industry and also the preoccupation over its deceleration in the context of the current economic and also environmental crisis. 
To guarantee the tourism sector resilience and timely response to crisis is very important to develop efficient human resource policies and personnel management plans. The study shows that this was one of the responses in Phuket, Thailand and Los Cabos, Mexico.

Finally, a scheme of both information gathering and monitoring on the crisis's real impacts, on the one hand, and also on the private sector's perceptions to assess the performance of the tourism sector, on the other, should be established. This would make it possible to develop more proactive strategies, such as the diversification of tourist markets; to take effective steps to improve the level of hotels' competitiveness based on product differentiation and higher quality of their human capital; to turn towards environmentally sustainable operation mechanisms; and to develop corporate social responsibility, to name a few. These elements, in addition to being beneficial to workers, enhance the tourist image of the region. This set of policies could help avoid the decline of hotel rates, and thus the loss of their status as luxurious destinations, which has given them comparative advantage in the international tourism market. The better training and policies of human resource management, as well as to the uniqueness of the site could be key elements for the successful continuation of the tourist industry in Phuket and Los Cabos.

Meeting the challenge of moving toward a knowledge-based economy in the tourism industry is obviously connected to the employment. The changes required in the quality of the labour force, in the way labour markets operate in order to increase productivity, and in the new institutions required to provide economic security to those changing or losing jobs are all essential to accelerate the transition toward a knowledge- based economy.

Being conscious of the need for change is the first important step in the long process we have before us. The impacts of the crisis demonstrated the urgency of this change. We sincerely hope that this work contributes to advance this process, which is necessary to create better skilled and more competitive human capital that will enable the tourism industry of Mexico and Thailand to more effectively participate in the world marketplace and to be more resilient to the crisis impacts.

Co-operation between countries could help confront the crisis and minimize the negative effects on people, enterprises, rights, and decent work. APEC can play a leading role in creating much better policy coherence at national, regional and international levels.

\section{REFERENCES}

[1] Gámez, A., Ivanova A. \& Campiranon K., Tourism, vulnerability, and economic crisis within APEC: responses from international destinations - Phuket, Thailand and Los Cabos, Mexico, Ravage of the Planet 2011, 3rd International Conference on Management of Natural Resources, Sustainable Development and Ecological Hazards, - December 2011, Malaysia.

[2] Aktas, G. \& Gunlu, E., Crisis management in tourist destinations. Global Tourism, 3rd ed., ed. W. Theobald, Elsevier Inc.: New York, pp. 440-455, 2005.

[3] Foxlley, A., Recovery. The Global Financial Crisis and Middle-Income Countries. Carnegie Endowment for International Peace: Washington, D.C., 2009, http://www.carnegieendowment. org/files/middle_income.pdf

[4] Angeles, M. \& Gamez, A., Globalización y desarrollo regional, el caso del sector turismo en Baja California Sur. Globalización y regionalismo: economía y sustentabilidad, eds. A. Ivanova \& A, Guillen, Porrúa: Mexico, 2008.

[5] Ketter, E., Marketing in Times of Financial Crisis: Tourism Recovery Strategies for Turbulent Times, 2009, available at http://www.travelvideo.tv/news/travel-industry-info/06-03-2009/ marketing-in-times-of-financial-crisis-tourism-recovery-strategies-for-turbulent-times

[6] Theparat, C., Surapong reviews tourism stimulus idea, Bangkok Post, 29th August, 2008, available at http://www.bangkokpost.com/040808_Business/04Aug2008_biz017.php 
[7] APEC Secretariat. Key Indicators Database, Asia Pacific Economic Cooperation, 2011, Available at: http://statistics.apec.org/index.php/key_indicator/kid_result/67

[8] Beirman, D., A Strategic Approach for the Global Tourism Industry to Overcome the Global Economic Crisis: A 10-Point Plan for Tourism Recovery, 2011, Available at: http://www. destinationworld.info/newsletter/feature60.html

[9] Martinez Alier, J., Socially sustainable economic de-growth. Development and Change, 40(6), 1099-1119, 2009. doi: http://dx.doi.org/10.1111/j.1467-7660.2009.01618.x

[10] WTO, World Tourism Organization. Healthy Growth of International Tourism in First Half of 2011, World Tourism Organization: Madrid, 2011.

[11] WTTC, World Travel \& Tourism Council. Travel \& Tourism Economic Impact, World Travel \& Tourism Council, 2011, London, available at http://www.wttc.org/research/economic-impactresearch/

[12] Pacific Asia Travel Association. Currencies and Oil Prices Challenge Asia Pacific Travel and Tourism, Bangkok: Pacific Asia Travel Association, 2008, available at http://www.pata.org/ patasite/index.php?id=1868

[13] World Tourism Organization. Tourism feels cash squeeze, UNWTO World Tourism Barometer, 2009, available at: http://www.bangkokpost.com/travel/travelnews/11492/tourism-feels-cashsqueeze

[14] Muller, D.K. \& Jansson, B., Tourism in Peripheries: Perspectives from the Far North and South. Wallingford: CAB International, 2007. doi: http://dx.doi.org/10.1079/9781845931773.0000

[15] Faulkner, B., Towards a Framework for tourism disaster management. Tourism Management, 22(2): 135-147, 2001. doi: http://dx.doi.org/10.1016/S0261-5177(00)00048-0

[16] Zehir, C., The activation level of crises and the change of strategic targets of enterprises in turkey during the depression era. Journal of American Academy of Business, Cambridge, 6(2), 293-300, 2005.

[17] C9 Hotelworks. Phuket 2009 Hotel Market Update, 2010, available at http://www.deliveringcommunications.com/campaigns/c9/docs/C9-Phuket-Hotel-Update-Jan2010.pdf

[18] Coombs, T., Ongoing Crisis Communication: Planning, Managing, and Responding, Sage Publications: London, 1999.

[19] The Phuket News. TAT Looks to Counter Low Season Lull, 2011, available at http://www. thephuketnews.com/wp-post.php?id=24664

[20] Cevallos, D., Economy-Mexico: Stimulus Plan to Curb Impacts of Crisis, 2009, available at http://news.alibaba.com/article/detail/markets/100193057-1-mexico-lawmakers-adopt-taxplan\%252C.html

[21] Pacific Asia Travel Association. Another Robust Year for Tourism in Asia and Pakistan, Pacific Asia Travel Association: Bangkok, 2007, available at http://www.unwto.org/newsroom/ Releases/2007/may/pakistan.htm

[22] Moreira, P., Aftermath of crises and disasters: notes for an impact assessment approach. Crisis Management in Tourism, eds. E. Laws, B. Prideaux \& K. Chon, CAB International: Wallingford, 51-65, 2007.

[23] Bland, M., Communicating Out of a Crisis, Macmillan Press: London, 1998.

[24] Mitroff, I., Pearson, M. \& Harrrington, L., The Essential Guide to Managing Corporate Crisis, Oxford University Press: Oxford, 1996.

[25] Lyon, A. \& Worton, A., A Proposed model for tourism crisis management: the UK's Foot and Mouth disease crisis analysed. Crisis Management in Tourism, eds. E. Laws, B. Prideaux \& K. Chon, CAB International: Wallingford, 200-216, 2007. doi: http://dx.doi.org/ $\underline{10.1079 / 9781845930479.0200}$ 
[26] IPCC, Intergovernmental Panel on Climate Change. Climate Change 2007, Cambridge University Press: Cambridge, 2007.

[27] Pechlaner, H., Abfalter, D., Raich, F. \& Dreyer, A., Crisis management and tourism organizations: A comparative study in the European Alps. Crisis Management in Tourism, eds. E. Laws, B. Prideaux \& K. Chon, CAB International: Wallingford, 157-169, 2007. doi: http://dx.doi. org/10.1079/9781845930479.0157

[28] Prideaux, B. \& Laws, E., Reflections and further research priorities. Crisis Management in Tourism, eds. E. Laws, B. Prideaux \& K. Chon, CAB International: Wallingford, 375-388, 2007. doi: http://dx.doi.org/10.1079/9781845930479.0375

[29] Laws, E., Prideaux, B. \& Chon, K., Crisis management in tourism: challenges for managers and researchers. Crisis Management in Tourism CAB International, eds. E. Laws, B. Prideaux \& K. Chon, Wallingford: Oxford, 1-12, 2007. doi: http://dx.doi.org/10.1079/9781845930479.0000

[30] Thai Websites. Thailand: Tourist Arrivals from 1998 till 2010. Quarterly Data 2007-2010, 2011, available at http://www.thaiwebsites.com/tourism.asp

[31] Koldowski, J., Tourism Thailand: going for quality or quantity? In PATA Thailand Chapter Marketing Seminar, "Quality or Quantity?" What is Best for Thailand and its Tourism Industries? February 18, Bangkok: PATA, 2009.

[32] Tourism Internet Marketing. Why Discounting Won't Work to Survive this Recession, Tourism Internet Marketing, 2009, available at http://tourisminternetmarketing.com/featured/whydiscounting-wont-work-to-survive-this-recession/

[33] Wilks, J. \& Moore, S., Tourism Risk Management for the Asia-Pacific Region: An Authoritative Guide for Managing Crisis and Disasters, APEC International Centre for Sustainable Tourism (AICST), Pacific Asia Travel Association (PATA) and World Tourism Organization (WTO), Australia, 2004, available at http://publications.apec.org/publication-detail.php?pub_id=461

[34] Bethan, E., Women Workers Pay the Price for the Global Economic Crisis, Oxfam, GB, March 2009, available athttp://www.oxfam.org.uk/resources/policy/economic_crisis/impacon_women. html

[35] IMF, International Monetary Fund. Western Hemisphere: Crisis Averted, What's Next? Regional Economic Outlook, International Monetary Fund: Washington, 2009.

[36] Lesova, P., Echoes of Asian Crisis Revertebrate in Thailand, Special Report, Marketwatch: Bangkok, November, 16, 2008.

[37] ILO Regional Office for Asia and the Pacific. "The fallout in Asia: Assessing labour market impacts and national policy responses to the global financial crisis", Responding to the Economic Crisis - Coherent Policies for Growth, Employment and Decent Work in Asia and Pacific, International Labour Organization, Manila, Philippines, 18-20 February, 2009, available at: http:// www.ilo.org/wcmsp5/groups/public/---asia/---ro-bangkok/documents/meetingdocument/ wcms_101730.pdf

[38] Didier, T., Hevia, C. \& Schmukler, S.L. How Resilient Were Emerging Economies to the Global Crisis? Research Working Paper Series, World Bank: Washington, 2011.

[39] Secretaría del Trabajo y Previsión Social. Acuerdo Nacional en favor de la Economía Familiar y el Empleo para Vivir Mejor, 9 d enero de 2009, STPS, México, available at http://www.stps. gob.mx/saladeprensa/discursos_2009/enero_stps.htm

[40] Ortiz, G., La crisis de 1994-95 y la actual crisis, CNN Expansión, 2009, available at http:// www.cnnexpansion.com/economia/2009/01/30/la-crisis-del-199495-y-la-actual-crisis

[41] Rangel, J.E. \& Ivanova, A., The Crisis in two Pacific Rim Economies: Higher Education and Employment in Mexico and Thailand, WIT Press: Wessex, 2011. 
[42] Tourism Authority of Thailand. Phuket, February, 2010, available at http://tourismthailand.org/ destination-guide/phuket-83-1-1.html

[43] Mantanarat, R., TAT Sells Phuket Great Time, April, 2011, available at http://www.ttrweekly. com/site/2011/04/tat-sells-phuket-great-time/.

[44] Ruff, P. \& Aziz, K., Managing Communications in a Crisis. Gower Publishing Limited: England, 2003.

[45] International Labour Organization. Thai Trade Unions Discuss Effective Responses to the Global Economic Crisis, Proceedings, ILO (International Labour Organization)/Thai Trade Unions High Level Workshop on Effective Trade Union Responses to the Global Economic Crisis, Bangkok, 2009, Available at http://www.ilo.org/asia/info/public/pr/langen/WCMS_101799/ ind x.htm

[46] Kaenkrachang, P., Phuket the Most Expensive Place to Live, 2010, available at http://phuketwan. com/jobs/phuket-expensive-place-live-work-13364/.

[47] Khamlo, A., Phuket Tourism: Has Phuket been Ruined by Tourism? 2011, available at http:// www.phuketgazette.net/archives/phuketlifestyle/2011/article9934.html

[48] The Phuket News. Phuket Hosted Seminar "Tourism \& Business in Phuket: Risk \& Challenges from Climate Change", The Phuket News, Phuket, Thailand, October 7th, 2010, available at http://phuketnews.phuketindex.com/environment/phuket-climate-change-180997.html

[49] Gamez, A. \& Angeles, M., Borders within. Tourism growth, migration and regional polarization in Baja California Sur (Mexico), Journal of Borderland Studies, 25(1), ABS Association, USA, 1-18, 2010.

[50] La Jornada. Cae ocupación hotelera en Los Cabos a 20 por ciento, Thursday, May 14th, Mexico, 2009, available at http://www.jornada.unam.mx/2009/05/14/index.php?section=esta dos\&article $=036$ n1 est.

[51] King Dejardin, A. \& Owens, J., Asia in the Global Economic Crisis: Impacts and Responses from a Gender Perspective, Paper presented on Responses to the Economic Crisis-Coherent Policies for Growth, Manila, Philippines, February, 2009.

[52] World Tourism Organization. Crisis Guidelines for the Tourism Industry, World Tourism Organization, 2003, available at http://www.world-tourism.org/market_research/recovery/ Crisis\%20and\%20Disaster\%20Management\%20Guidelines.pdf\#search $=\% 22 \% 22$ Crisis $\% 20$ Guidelines\%20for\%20the\%20Tourism\%20Industry\%22\%20wto\%22 